\title{
Epizoic arthropods of the Mexican Shrew, Sorex oreopolus (Mammalia: Soricidae)
}

\author{
Griselda Montiel-Parra ${ }^{1 *}$, Ana Lilia Carlos-Delgado ${ }^{1}$, Ricardo Paredes-León ${ }^{1}$ and Tila M. Pérez ${ }^{1}$ \\ ${ }^{1}$ Colección Nacional de Ácaros (CNAC), Departamento de Zoología, Instituto de Biología, Universidad Nacional Autónoma de \\ México. Circuito exterior s/n, Coyoacán, CP. 04510. Ciudad de México, México. Email: grismp@ib.unam.mx (GMP), anli cdel@ \\ hotmail.com (ALCD), rparedes@st.ib.unam.mx (RPL), tilam@ib.unam.mx (TMP). \\ * Corresponding author
}

\begin{abstract}
Shrews (Eulipotyphla: Soricidae) are amongst the most diverse and widely distributed groups of small mammals worldwide. In Mexico, more than 40 species of the genera Sorex, Cryptotis, Megasorex, and Notiosorex have been documented. There is little knowledge about epizoic arthropods of shrews, with 40 species recorded, 28 corresponding to the subclass Acari, and 12 to Insecta. Sorex oreopolus Merriam, 1892, is an endemic species of Mexico, distributed from southwest Jalisco to east Puebla and west Veracruz. This study reports the first records of epizoic arthropods of S. oreopolus. Five specimens of S. oreopolus were collected during 2016 from four sites at La Malinche National Park, state of Tlaxcala. Epizoic arthropods were removed from the pelage of shrews and processed for identification. For each species found in S. oreopolus, ecological parameters of infestation were calculated; for parasitic species, also the degree of host specificity was estimated. A total of 1,194 arthropods were found, corresponding to six mite and one insect taxa. All are new records for this host species. The mites Orycteroxenus soricis (Oudemans 1915) and Pygmephorus horridus Mahunka, 1973 are recorded for the first time in Mexico. The prevalence and abundance of O. soricis was high, while Corrodopsylla lira Traub, 1950 is less prevalent/abundant (Table 1). Epizoic arthropods comprise commensals (Myobiidae), temporary ectoparasites (Trombiculidae) and (Ctenophthalmidae), and phoretic (Glycyphagidae and Pygmephoridae). Seven taxa of epizoic arthropods recorded in this study represent the first record of association with $S$. oreopolus. The mites $O$. soricis and $P$. horridus had already been documented on shrews of the genus Sorex; however, they are recorded for the first time in Mexico, increasing the richness of symbionts of Mexican shrews from 40 to 42 species. Further investigations on the richness of arthropods associated with Mexican shrews are needed, as only seven of 40 species of shrews have been documented, representing $20 \%$ of hosts.
\end{abstract}

Las musarañas (Eulipotyphla, Soricidae) constituyen uno de los grupos de mamíferos pequeños terrestres más diverso y con mayor distribución en el mundo. En México se encuentran en casi todo el territorio y se han documentado más de 40 especies de los géneros, Sorex, Cryptotis, Megasorex y Notiosorex. Es notable la falta de estudios sobre los artrópodos epizoicos de musarañas en el país, se han registrado 40 especies de los cuales 28 corresponden a la Subclase Acari y 12 a la Clase Insecta, asociados a siete especies de musarañas. La musaraña mexicana Sorex oreopolus Merriam, 1892 es una especie endémica de México, que se distribuye desde el extremo suroeste de Jalisco hasta el este de Puebla y oeste de Veracruz. Hasta la fecha no se han documentado sus artrópodos epizoicos, por lo que el objetivo de este trabajo es presentar los primeros registros. Durante el 2016 se recolectaron cinco ejemplares de S. oreopolus en cuatro sitios del Parque Nacional La Malinche en el estado de Tlaxcala. Los artrópodos epizoicos se extrajeron y procesaron para su identificación. Se calcularon los parámetros ecológicos de infestación: prevalencia, abundancia promedio, intensidad promedio e intervalo de intensidad para cada especie de ácaro. Se recuperaron 1,194 artrópodos epizoicos distribuidos en 6 taxones de ácaros y un taxón de insecto, todos representan nuevos registros para el huésped. El ácaro Orycteroxenus soricis (Oudemans 1915) presentó los niveles más altos de abundancia y prevalencia, mientras que los valores más bajos de infestación fueron para la pulga Corrodpsylla lira Traub, 1950 (Cuadro 1). Por primera vez en México, se registran los ácaros O. soricis y Pygmephorus horridus Mahunka, 1973. Los simbiontes presentaron tres categorías de asociación: comensales (Myobiidae), ectoparásitos temporales (Trombiculidae) y (Ctenophthalmidae) y foréticos (Glycyphagidae y Pygmephoridae). Los siete taxones de artrópodos epizoicos registrados en este estudio representan el primer registro de asociación con S. oreopolus. Los ácaros O. soricis y $P$. horridus, ya habían sido documentadas sobre las musarañas del género Sorex, no obstante, se registran por primera vez en México, incrementando la riqueza de simbiontes de musarañas mexicanas de 40 a 42 especies. Se necesitan investigaciones adicionales sobre la riqueza de artrópodos asociados, ya que sólo se han documentado en siete de las más de 40 especies de musarañas mexicanas, lo cual representa cerca del $20 \%$ de los huéspedes.

Keywords: Mexico; mites; Orycteroxenus soricis; parque nacional La Malinche; shrews; symbiosis.

(c) 2019 Asociación Mexicana de Mastozoología, www.mastozoologiamexicana.org

\section{Introduction}

Shrews (Eulipotyphla, Soricidae) are one of the most diverse and more extensively distributed groups of terrestrial small mammals worldwide. In Mexico, shrews are found across the whole country (Carraway 2007) with more than 40 species of 4 genera documented, grouped in 3 tribes: 1) Soricini, including the genus Sorex. 2) Blarinini, with Cryptotis. 3) Notiosoricini, grouping together Megasorex and Notiosorex (Guevara et al. 2014, 2015; Matson and Ordóñez-Garza 2017; Ramírez-Pulido et al. 2014). Shrews consume large amounts of invertebrates, including worms, crustaceans, and spiders, as well as insects and their larvae (Hope et al. 2016). In addition, they a diverse and abundant associated fauna (mainly parasites) (Binkienè et al. 2011; Morrone and Acosta 2006). Shrews and their parasites are key indicators to anticipate the consequences of environmental disruption and changes in the interactions between species (Hope et al. 2016).

In Mexico, studies about ectoparasites of shrews are particularly scarce; only 40 species of ectoparasites have 
been recorded to date, with 28 corresponding to the Subclass Acari and 12 to the Class Insecta, associated with seven species of shrews: Cryptotis mexicanus, C. magnus, Cryptotis sp., Notiosorex crawfordi, Sorex milleri, S. saussurei, S. veraepacis, S. salvini (= S. veraecrucis), and Sorex sp. (Estébanes-González and Cervantes 2005; Fain and Estebanes 1996; Montiel-Parra et al. 2009; Morrone and Acosta 2006; Salceda-Sánchez and Hastriter 2006; Vargas et al. 2009; Whitaker and Morales-Malacara 2005).

The shrew S. oreopolus Merriam, 1892, is a endemic species endemic of Mexico, distributed from the southwestern end of Jalisco to east Puebla and west Veracruz; living in mountain forests dominated by conifers and oaks, as well as by sacaton meadow (Castro-Arellano 2005). Ectoparasites or other arthropods associated with this species have not been documented yet; hence, this study reports the first records of epizoic arthropods of S. oreopolus.

\section{Methods}

In 2016, pitfall traps were placed around the area known as La Cañada Grande, located on the eastern slope of La Malinche (Malintzi or Matlalcueyatl) volcano at La Malinche National Park (Lopez-Dominguez and Acosta 2005; Figure 1a-c). Shrews were collected from two habitats representative of the park: pine forest and pine-oak forest (Figure 1d-e, e). At each site, eight pitfall traps were placed, each consisting of a 1,000 ml plastic container with ethylene glycol as preservative. Traps were left for 72 hours; subsequently, all the specimens captured were collected and deposited in glass bottles with $80 \%$ ethanol. Only five shrews were captured in four sites (Figure 1d-e); these were removed from traps and individually preserved in $96 \%$ ethanol bottles for transportation to the Colección Nacional de Ácaros (CNAC) at Instituto de Biología, Universidad Nacional Autónoma de Mexico (IB-UNAM) in Mexico City. The body surface of each shrew was examined, brushing the pelage over a sheet of paper that was subsequently examined under a stereomicroscope; also, the ethanol where specimens were preserved was examined to obtain any ectoparasites that may have detached from the host. The sampling of shrews was carried out under collection licenses issued by SEMARNAT (FAUT-0309 and FAUT-0002). Shrews were identified and deposited in the Colección Nacional de Mamíferos (CNMA) of IB-UNAM, recorded with the following data: 1 unsexed specimen (UNAM 839/CNMA 49505), $5.4 \mathrm{~km}$ road to Estación Científica del Parque Nacional La Malinche, Mpio.
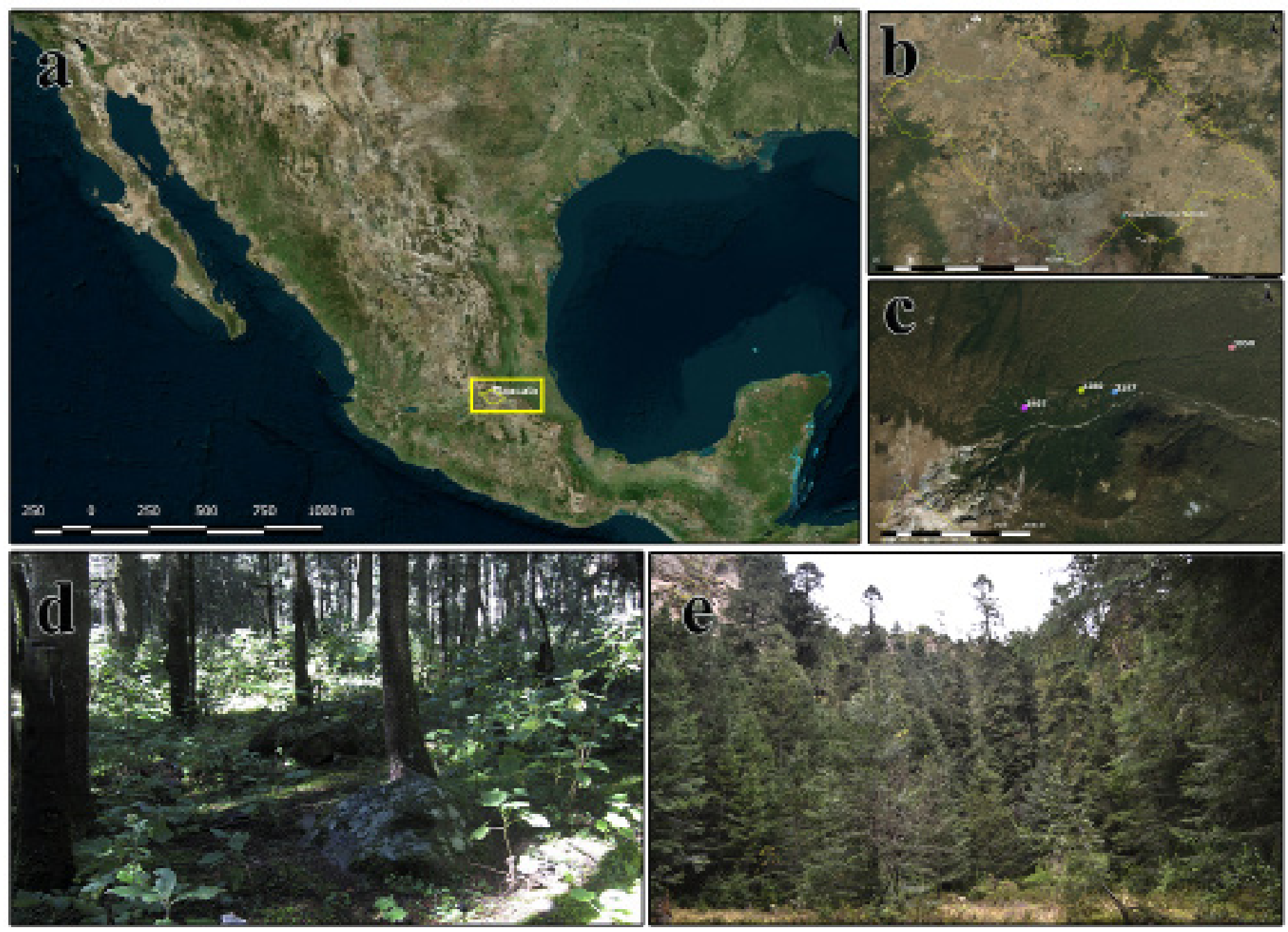

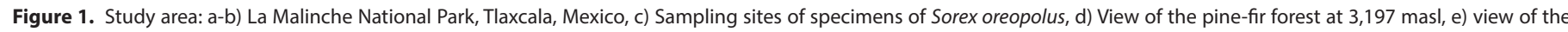
pine forest at 3,407 masl. 
Ixtenco, Tlaxcala, 1 Abril 2016, 19.25290 N, -97.97917W, 3,050 msnm, Bosque de Pino, A. Valdez, E. Briones, M. Cortez, A. Juárez, cols.; 1 unsexed specimen (UNAM 840 /CNMA 49511), $1.5 \mathrm{~km}$ al oeste de la Estación Científica del Parque Nacional La Malinche, Mpio. Ixtenco, Tlaxcala, 6 mayo 2016, 19.24594 ${ }^{\circ} \mathrm{N},-98.00336^{\circ} \mathrm{W}, 3,250 \mathrm{msnm}$, Bosque de Oyamel-Pino, A. Valdez col.; 1 \& (UNAM 858/CNMA 49509), $2.5 \mathrm{~km}$ al oeste de la Estación Científica La Malinche, Mpio. Ixtenco, sobre la Cañada Grande, 2 junio 2016, 19.24309 $\mathrm{N}$, $-98.01241^{\circ} \mathrm{W}, 3,407 \mathrm{msnm}$, Bosque de Oyamel-Pino, A. Valdez and E. Briones, cols.; 1 s same data except (UNAM 859/ CNMA 49510); and 1 (UNAM860/CNMA 49508), $800 \mathrm{~km}$ al oeste de la Estación Científica La Malinche, 1 diciembre 2016, 19.24565 N, $-97.99799^{\circ}$ W, 3,197 msnm, Bosque de Oyamel-Pino, A. Valdez, E. Briones and M. Cortez, cols. For the determination, mites were cleared with lactophenol and mounted between microscope slides in Hoyer's medium. The siphonapteran (Insecta) was cleared with $\mathrm{KOH}$ and mounted in Canada Balsam. Ectoparasites are deposited in the CNAC. For each mite species, the following ecological infestation parameters were estimated: prevalence, mean abundance, mean intensity, and intensity range (Bush et al. 1997). In the case of parasites, the degree of specificity was determined considering the monoxenous, stenoxenous and oligoxenous (Herrin and Tipton 1975).

\section{Results}

From the five specimens of $S$. oreopolus captured, a total of 1,194 ectoparasites we collected, distributed in seven taxa, six belonging to the subclass Acari, within four families and six genera. One flea Corrodopsylla lira Traub, 1950, family Ctenophthalmidae, was found (Table 1). A female of S. oreopolus captured in December six of the seven taxa reported in this study.

Table 1. Species of epizoic arthropods of Sorex oreopolus at La Malinche National Park, Tlaxcala, Mexico.



The symbionts found were classified into three association categories: 1 ) commensals (Myobiidae). 2) temporary ectoparasites (Trombiculidae and Ctenophathalmidae). 3) phoretic (Glycyphagidae and Pygmephoridae).

Mites of the family Myobiidae (Figure 2a, b) showed a high host specificity, supporting the proposed phylogenetic relationships between their hosts. It has been observed that species can be oligoxenous (a parasite associated with two or more species of different genera but belonging to the same subfamily); for instance, the species of Protomyobia, Amorphacarus, and Blarinobia are all parasites especific to the subfamily Soricinae (Jameson 1984; Fain 1979). The specimens of Protomyobia sp. and Amorphacarus sp. found in S. oreopolus could not be identified to species because only an adult was found, the rest being either tritonymphs or protonymphs. Immature stages of this family have been little studied and differ morphologically from adults (Bochkov and Mirolubov 2015).

Temporary parasites of the family Trombiculidae are associated with the host for a short period of time during a single stage of their life cycle (hexapod larvae); these larvae feed on lymph and can be carriers and transmitters of bacteria or other microorganisms, whereas adults and nymphs are free-living (Hoffmann 1990). The species Walchioides intrinseca (Brennan 1960) (Figure 2c) has only been found in central Mexico, associated with Sorex saussurei Merriam, 1892 in Mexico City and with Sorex sp. in the state of Morelos (Hoffmann 1990). W. intrinseca is a stenoxene parasite (i. e., associated with two or more host species of the same genus).

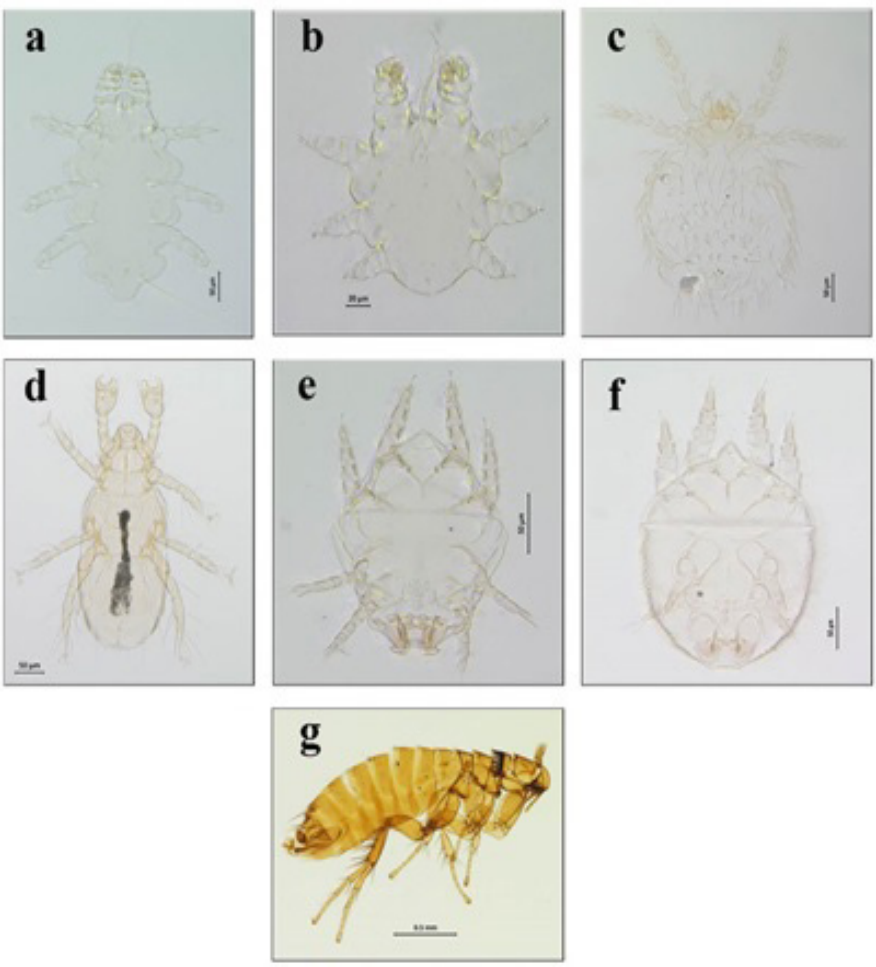

Figure 2. Epizoic arthropods of Sorex oreopolus at La Malinche National Park, Tlaxcala, Mexico: a) Amorphacarus sp. (female); b) Protomyobia sp. (protonymph); c) Walchioides intrinseca (larva); d) Pygmephorus horridus (female); e) (Orycteroxenus soricis (deutonymph); f) Xenoryctes sp. (deutonymph); g) Corrodopsylla lira (male) 
Dimorphic females of the family Pygmephoridae are characterized by a markedly modified leg I, with large grooved claws used for passive dispersal (phoresia) on small mammals (Eulipotyphla, Rodentia, and Lagomorpha), being less frequent in nests, and rarely found in soil or litter samples; other aspects of the biology of this family are unknown (Dastych et al. 1991). In Mexico, Pygmephorus americanus Banks 1904, has been previously recorded (Smiley 1978); therefore, Pygmephorus horridus Mahunka 1973 (Figure 2d) represents the second species of this family reported in the country, in addition to being the first record in association with soricid mammals. P. horridus has been collected in association with Blarina brevicauda (Say 1823) and Scalopus aquaticus (Linnaeus 1758) in the United States of America (Mahunka 1973).

Several deutonymphs (a post-embryonic development stage of mites between larva and adult) of species of the family Glycyphagidae have been recorded in American shrews. Ninety six per cent of the symbionts found in S. oreopolus belong to this family. Orycteroxenus soricis (Oudemans 1915; Figure 1e) showed the highest infestation levels (1,152 individuals), a $100 \%$ prevalence, and a mean abundance of 230.4 mites per shrew, with an intensity range of 2 to 466 mites (Table 1). This species has been collected in shrews of the genera Sorex and Blarina in North America (Whitaker and Richards 2005). In Mexico, the species Orycteroxenus mexicanus Lukoschus et al. 1977 has been reported associated with shrews of the genera Cryptotis and Sorex; Orycteroxenus notiosorex Lukoschus et al. 1977, in Notiosorex crawfordi (Coues 1877); and Orycteroxenus sp., in Sorex salvini Merriam 1897 (Whitaker and Morales-Malacara 2005; Vargas et al. 2009). On the other hand, Xenoryctes sp. (Figure $2 \mathrm{f}$ ) has been previously recorded in S. salvini (Vargas et al. 2009). However, the two deutonymphs found differ from the species already described; therefore, additional specimens of $S$. oreopolus should be examined to confirm whether the specimens found in this study correspond to a new species.

The flea C. lira Traub, 1950 (Siphonaptera, Figure 2g) showed the lowest infestation values (Table 1). It has been recorded in S. saussurei and Sorex milleri from Mexico City, Michoacán, and Nuevo León (Morales-Muciño and Llorente-Bousquets 1986), being considered as a stenoxenous or monoxenous (i. e., exclusive to a single host species) pasasite (Morrone and Acosta 2006).

\section{Discussion}

The seven epizoic arthropod taxa documented in this study represent the first record in association with S. oreopolus. The mites $O$. soricis and $P$. horridus had been documented previously on shrews of the genus Sorex (Fain 1969; Smiley and Whitaker 1984); however, our study is the first record for Mexico, increasing the richness of symbionts of Mexican shrews from 40 to 42 species.
Recent studies on Mexican shrews have contributed to advancing our knowledge about the richness, current distribution, and conservation of these species, as well as on their intra- and interspecies morphological variations (Guevara et al. 2015). However, further research is required on their epizoic arthropods, since this aspect has been for only seven of the more than 40 species of shrews, representing about $20 \%$ of hosts. For a better estimate the biodiversity of epizoic arthropods of $S$. oreopolus, a larger number of host specimens should be examined in order to obtain adult mites of the family Myobiidae, as well as deutonymphs of Glycyphagidae, seeking to determine the taxa recorded in this study to the species level. Further research should also address biological and ecological aspects of these arthropods to gain a deeper understanding of parasite-host systems, to set the grounds for understanding and documenting ecological changes, as well as other aspects about the biology of the species involved.

\section{Acknowledgments}

To Y. Hortelano-Moncada and L. Guevara for the determination of shrews and providing the CNMA catalog numbers. To R. Acosta for confirming the identification of the siphonapteran specimen. To E. Briones and A. Valdez for the information provided about the study site and the donation of shrews. To S. Guzman for the photograph of the siphonapteran and to assistance in the laboratory at LaNaBio, IBUNAM. María Elena Sánchez-Salazar translated the manuscript into English.

\section{Literature cited}

Binkiene, R., V. Kontrimavichus, and E. P. Hoberg. 2011. Overview of the Cestode fauna of European shrews of the genus Sorex with comments on the fauna in Neomys and Crocidura and an exploration of historical processes in post-glacial Europe. Helminthologia 48:207-228.

BochKov, A. V., AND A. A. Mirolubov. 2015. Description of postembrionic immature stages of Protomyobia onoi Jameson and Dusbabek, 1971 (Acariformes: Myobiidae) and comparative analysis of the juvenile external morphology in the tribe Protomyobiini. International Journal of Acarology 41:115-127.

Bush, A. O., K. D. Lafferty, J. M. Lotz, and A. W. Shostak. 1997. Parasitology meets ecology on its own terms: Margolis et al. revisited. The Journal of Parasitology 83:575-583.

Carraway, L. N. 2007. Shrews (Eulypotyphla: Soricidae) of Mexico. Monographs of the Western North American Naturalist 3:1-91.

Castro-Arellano, I. 2005. Sorex oreopolus. Pp. 148 in Los mamíferos silvestres de México (Ceballos, G., and G. Oliva, eds). Comisión Nacional para el Conocimiento y Uso de la Biodiversidad, Fondo de Cultura Económica. Ciudad de México, México.

DASTYCH, H., G. RACK, AND N. WILSON. 1991. Notes on mites of the genus Pygmephorus (Acari: Heterostigmata) associated with North American mammals. Mitteilungen aus dem Hamburgischen Zoologischen Museum und Institut 88:161-174. 
Estébanes-González, M. L., and F. Cervantes R. 2005. Mites and ticks associated with some small mammals in Mexico. International Journal of Acarology 31:23-37.

FAIN, A. 1969. Les deutonymphes hypopiales vivant en association phorétique sur les mammifères (Acarina: Sarcoptiformes). Bulletin Institut Royal des Sciences Naturelles de Belgique 45:1-262.

FAIN, A. 1979. Specificity, adaptation and parallel host-parasite evolution in acarines, especially Myobiidae, with a tentative explanation for the regressive evolution caused by the immunological reactions of the host. Pp. 321-332 in Recent Advances in Acarology, Vol. II (Rodriguez, J. G. ed.). Academic Press. New York, U. S. A.

Fain, A., AND M. L. Estebanes. 1996. New fur mites of the family Listrophoridae (Acari: Astigmata) from Mexico. International Journal of Acarology 22:181-186.

Guevara, L., V. Sánchez-Cordero, L. León-Paniagua, and N. Woodman. 2014. A new species of small-eared shrew (Mammalia, Eulipotyphla, Cryptotis) from the Lacandona rainforest, Mexico. Journal of Mammalogy 95:739-753.

Guevara, L., F. Cervantes R., And V. Sánchez-Cordero. 2015. Riqueza, distribución y conservación de los topos y las musarañas (Mammalia, Eulipotyphla) de México. Therya 6:43-68.

Herrin, C., AND V. Tipton. 1975. Spinturnicid mites of Venezuela (Acarina: Spinturnicidae). Brigham Young University Science Bulletin, Biological Series 20:1-72.

Hoffmann, A. 1990. Los trombicúlidos de México (Acarida: Trombiculidae), Parte taxonómica. Publicaciones Especiales del Instituto de Biología 2. Universidad Nacional Autónoma de México. Ciudad de México, México.

Hope, A. G., S. E. Greiman, V. V. Tkach, E. P. Hoberg, and J. A. Cook. 2016. Shrews and their Parasites: Small Species Indicate Big Changes. In Arctic Report Card 2016. http://www.arctic.noaa. gov/Report-Card. Consultada el 5 de noviembre 2018.

JAMESON, JR., E. W. 1984. Myobiid mites (Acarina: Myobiinae) from shrews (Mammalia: Soricidae) of eastern North America. The Journal of Parasitology 34:336-342.

López-Domínguez, J. C., And R. AcostA. 2005. Descripción del Parque Nacional Malinche. Pp. 3-24 in Biodiversidad del Parque Nacional La Malinche Tlaxcala, México (Fernández F., J. A., and J. C. López-Dominguez, eds.). Coordinación General de Ecología del Gobierno del Estado de Tlaxcala. Tlaxcala, México.

Mahunka, S. 1973. Pygmephorus species (Acari, Tarsonemida) from North American small mammals. Parasitologica Hungarica 6:247-259.

Matson, J. O., And N. Ordóñez-Garza. 2017. The taxonomic status of Long-tailed shrews (Mammalia: Genus Sorex) from Nuclear Central America. Zootaxa 4236:461-483.

Montiel-Parra, G., R. Paredes-León, C. Guzmán-Cornejo, Y. Hortelano-Moncada, and T. M. Pérez. 2009. Ácaros asociados a Vertebrados. Pp. 385-393 in Biodiversidad del ecosistema del Pedregal de San Ángel (Lot, A., and Z. Cano-Santana, eds.). Universidad Nacional Autónoma de México. Ciudad de México, México.

Morrone, J. J., And R. AcostA. 2006. A synopsis of the fleas (Insecta: Siphonaptera) parasitizing New World species of Soricidae (Mammalia: Insectivora). Zootaxa 1354:1-30.

Morales-Muciño, J. C., And J. Llorente-Bousquets. 1986. Estado actual del conocimiento de los Siphonaptera de México.
Anales del Instituto de Biología, Universidad Nacional Autónoma de México, Serie Zoología 56:497-554.

Ramírez-Pulido, J., N. González-Ruiz, A. L. Gardner, and J. ArroyoCabrales. 2014. List of Recent Land Mammals of Mexico, 2014. Special Publications Museum of Texas Tech University 63:1-69.

Salceda-SÁnchez, B., And M.W. Hastriter. 2006. A list of the fleas (Siphonaptera) of Mexico with new host and distribution records. Zootaxa 1296:29-43.

Smiley, R. L. 1978. Taxonomic studies of Pygmephorus species from the western hemisphere, with a key to females and an overview of the current problems for classification (Acari: Pyemotidae and Pygmephoridae). International Journal of Acarology 4:125-160.

SMILEY, R. L., AND J. O. WhitAKER, JR. 1984. Key to new and old world Pygmephorus species and descriptions of six new species (Acari: Pygmephoridae). International Journal of Acarology 10:59-73.

Vargas, M., F. A. Cervantes, G. Montiel-Parra, and S. Rubio-Hernández. 2009. Ectosimbiontes de la musaraña Sorex veraecrucis (Mammalia: Soricomorpha) del Estado de Veracruz, México. Pp. 265-270 in 60 Años de la Colección Nacional de Mamíferos del Instituto de Biología, UNAM. Aportaciones al Conocimiento y Conservación de los Mamíferos Mexicanos (Cervantes, F. A., Y. Hortelano M., and J. Vargas C., eds.). Instituto de Biología, UNAM. Ciudad de México, México.

Whitaker, J. O. JR., AND J. B. Morales-Malacara. 2005. Ectoparasites and other associates (Ectodytes) of mammals of Mexico. Pp. 535-666 in Contribuciones Mastozoológicas en Homenaje a Bernardo Villa (Sánchez-Cordero, V., and R. A. Medellín, eds.). Instituto de Biología, UNAM, Instituto de Ecología, UNAM, CONABIO. Ciudad de México, México.

WHITAKER, J. O. JR., AND R. L. RICHARDS. 2005. Shrews of Indiana: late Pleistocene to present. Pp. 2-48 in Advances in the Biology of shrews II (Merrit, J. F., R. Hutterer, S. Churchfield, and B. I. Sheftel, eds.). International Society of Shrew Biologists. New York, U. S. A.

Associated editor: Lazaro Guevara

Submitted: November 16, 2018; Reviewed: January 7, 2019; Accepted: January 17, 2019; Published on line: January 28, 2019. 
38 THERYA Vol. 10 (1): 33-37 